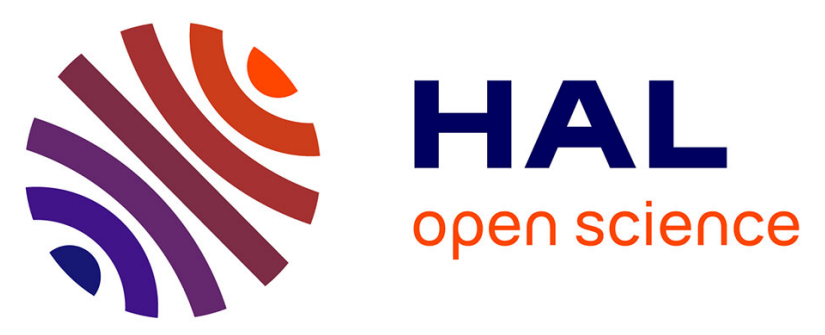

\title{
Foaming and adsorption behavior of bovine and camel proteins mixed layers at the air/water interface
}

Roua Lajnaf, Laetitia Palmade, Hamadi Attia, Sylvie Marchesseau, M.A. Ayadi

\section{- To cite this version:}

Roua Lajnaf, Laetitia Palmade, Hamadi Attia, Sylvie Marchesseau, M.A. Ayadi. Foaming and adsorption behavior of bovine and camel proteins mixed layers at the air/water interface. Colloids and Surfaces B: Biointerfaces, 2017, 151, pp.287-294. 10.1016/j.colsurfb.2016.12.010 . hal-01607329

\section{HAL Id: hal-01607329 https://hal.science/hal-01607329}

Submitted on 26 May 2020

HAL is a multi-disciplinary open access archive for the deposit and dissemination of scientific research documents, whether they are published or not. The documents may come from teaching and research institutions in France or abroad, or from public or private research centers.
L'archive ouverte pluridisciplinaire HAL, est destinée au dépôt et à la diffusion de documents scientifiques de niveau recherche, publiés ou non, émanant des établissements d'enseignement et de recherche français ou étrangers, des laboratoires publics ou privés. 


\section{Accepted Manuscript}

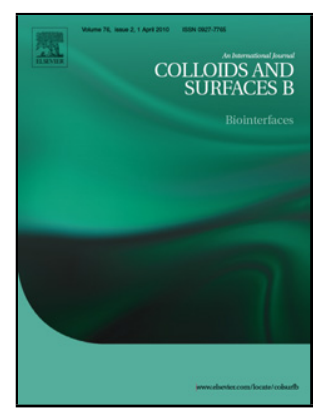

Title: Foaming and adsorption behavior of bovine and camel proteins mixed layers at the air/water interface

Author: Roua Lajnaf Laetitia Picart-Palmade Hamadi Attia Sylvie Marchesseau M.A. Ayadi

PII:

DOI:

Reference:

To appear in:

Received date:

Revised date:

Accepted date:

$$
\text { S0927-7765(16)30847-5 }
$$$$
\text { http://dx.doi.org/doi:10.1016/j.colsurfb.2016.12.010 }
$$$$
\text { COLSUB } 8287
$$

\section{Colloids and Surfaces B: Biointerfaces}

20-9-2016

$1-12-2016$

7-12-2016

Please cite this article as: Roua Lajnaf, Laetitia Picart-Palmade, Hamadi Attia, Sylvie Marchesseau, M.A.Ayadi, Foaming and adsorption behavior of bovine and camel proteins mixed layers at the air/water interface, Colloids and Surfaces B: Biointerfaces http://dx.doi.org/10.1016/j.colsurfb.2016.12.010

This is a PDF file of an unedited manuscript that has been accepted for publication. As a service to our customers we are providing this early version of the manuscript. The manuscript will undergo copyediting, typesetting, and review of the resulting proof before it is published in its final form. Please note that during the production process errors may be discovered which could affect the content, and all legal disclaimers that apply to the journal pertain. 
Foaming and adsorption behavior of bovine and camel proteins mixed layers at the air/water interface

Shortened Title: Foaming properties of camel and bovine properties

Roua Lajnaf ${ }^{\mathrm{a}, \mathrm{b}}$, Laetitia Picart-Palmade ${ }^{\mathrm{b}}$, Hamadi Attia ${ }^{\mathrm{a}}$, Sylvie Marchesseau ${ }^{\mathrm{b}}$, M.A. Ayadi ${ }^{\mathrm{a}}$

${ }^{a}$ Alimentary Analysis Unit, National Engineering School of Sfax, BPW 3038, Sfax, Tunisia

${ }^{\mathrm{b}}$ Montpellier University, UMR IATE, Place E. Bataillon, 34095 Montpellier Cedex 5, France

${ }^{1}$ Corresponding author:

Dr Mohamed Ali Ayadi,

LAVASA, ENIS, BP 3038, Sfax Tunisia

E-mail address : ayadimedali@yahoo.fr / ayadimedali@gmail.com

Tel / Fax : 0021674675761

Journal: Colloids and Surfaces B: Biointerfaces 


\section{Graphical abstract}

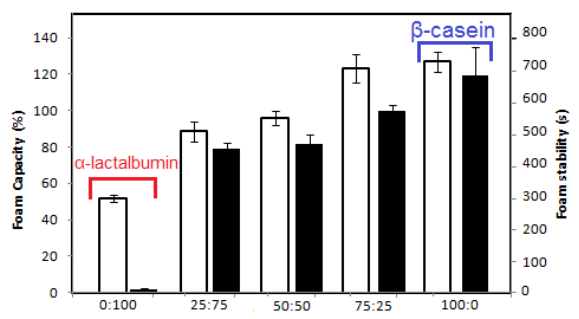

Camel $\alpha$-lactalbumin - $\beta$-casein mixed systems

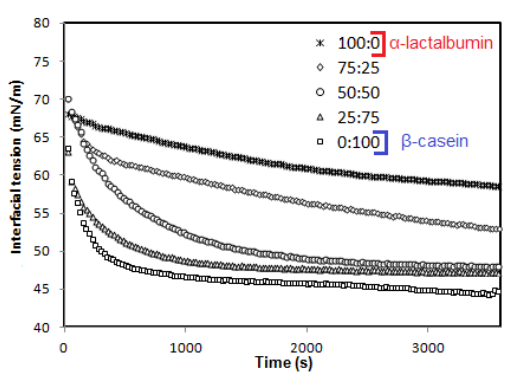

\section{Highlights}

- Camel $\alpha$-lactalbumin and $\beta$-casein were purified from camel milk.

- Foaming and interfacial properties of bovine and camel protein mixture were studied.

- $\quad \beta$-Casein mainly affects the foaming and interfacial properties of proteins mixture. 


\begin{abstract}
The aim of this work was to examine foaming and interfacial behavior of three milk protein mixtures, bovine $\alpha$-lactalbumin- $\beta$-casein (M1), camel $\alpha$-lactalbumin- $\beta$-casein (M2) and $\beta$ lactoglobulin- $\beta$-casein (M3), alone and in binary mixtures, at the air/water interface in order to better understand the foaming properties of bovine and camel milks. Different mixture ratios $(100: 0 ; 75: 25 ; 50: 50 ; 25: 75 ; 0: 100)$ were used during foaming tests and interfacial protein interactions were studied with a pendant drop tensiometer. Experimental results evidenced that the greatest foam was obtained with a higher $\beta$-casein amount in all camel and bovine mixtures. Good correlation was observed with the adsorption and the interfacial rheological properties of camel and bovine protein mixtures. The proteins adsorbed layers are mainly affected by the presence of $\beta$-casein molecules, which are probably the most abundant protein at interface and the most efficient in reducing the interfacial properties. In contrast of the globular proteins: $\alpha$-lactalbumin and $\beta$-lactoglobulin which involved in the protein layer composition but could not compact well at the interface to ensure foams creation and stabilization because of their rigid molecular structure.
\end{abstract}

Keywords : Camel milk, $\alpha$-lactalbumin, $\beta$-casein, $\beta$-lactoglobulin, Mixed systems, Foaming properties. 


\section{Introduction}

Camel milk is one of the main food resources for populations in hot regions and arid countries. It contains all nutrient components (protein, fat, lactose, minerals) already found in bovine milk and has an interesting biological value due to its contents of antimicrobial factors such as lactoferrin, lysozyme and immunoglobulins [1]. Camel milk proteins can be classified, as milks of other mammalian species, into two main components: caseins and whey proteins. Casein is the major protein fraction in camel milk representing $75.4 \%$ of the total proteins [2]. The $\beta$-casein is the main camel milk casein constituting about $65 \%$ of total casein fraction (compared with $36 \%$ in bovine milk) [3]. Molecular weight of camel $\beta$-casein $(24.65 \mathrm{kDa})$ is higher compared to that of bovine $\beta$-casein $(23.58 \mathrm{kDa})$, and the numbers of amino acid residues in camel and bovine $\beta$-casein are 217 and 209 respectively as reported by [4]. Sequence alignment of bovine and camel $\beta$-casein shows that the sequence similarity and identity between these two caseins are $84.5 \%$ and $67.2 \%$, respectively [5].

Whey proteins are the second main component of camel milk protein fraction constituting $20-25 \%$ of the total proteins. Overall, in bovine whey proteins, the $\beta$-lactoglobulin is the main component among bovine whey proteins (50\%) followed by the $\alpha$-lactalbumin $(25 \%)$. However, in camel whey, $\beta$-lactoglobulin is deficient [6-8] and the $\alpha$-lactalbumin is the major camel whey protein with an average concentration of $2.2 \mathrm{~g} / \mathrm{l}$ which is significantly higher than the $\alpha$-lactalbumin content in bovine milk (0.5 g/l) [9]. Similarly to bovine $\alpha$-lactalbumin, that of the camel milk has 123 aminoacid residues forming a compact globular protein. Its molecular weight is around $14.6 \mathrm{kDa}$ and its isoelectric point is between $4.1-4.8$ [10]. The sequence alignment of bovine and camel $\alpha$-lactalbumin indicates that 39 aminoacid residues are different between the bovine and the camel $\alpha$-lactalbumin sequences, thus, the similarity and identity between these two proteins are $82.9 \%$ and $69.1 \%$ respectively $[10,11]$.

Milk foams are colloidal systems in which air bubbles are integrated and stabilized by a matrix composed of milk components [12]. The surface active agents used in foam creation in milk are mainly proteins which are characterized by their ability to: (1) absorb at the air/water interface, leading to a decrease of surface tension, (2) spread at the interface after orienting the hydrophilic and hydrophobic groups of the protein at the aqueous and non-aqueous phases, respectively, and (3) form a film by using the interactions of proteins. The foaming behavior of milk protein is determined by its structural, compositional and physical characteristics, such as amino acid sequence composition, molar mass, tertiary structure, surface charge and hydrophobicity [13]. 
Milk proteins can be classified in two main groups with very different surface rheological properties: flexible caseins and globular whey proteins. Flexible caseins have no tertiary structure including $\alpha_{\mathrm{S}^{-}}, \alpha_{\mathrm{S} 2^{-}}, \beta$ - and $\mathrm{K}$-casein. Whereas, globular proteins are characterized by containing disulphide bridges and tertiary structure $[14,15]$. Thus, flexible proteins can change their conformation at the interface more easily than globular ones which preserve their molecular shape even after adsorption on an interface [16,17].

Starting from these considerations it seems very interesting, for potential applications in industrial foam production, to compare the foaming and interfacial properties of binary mixtures of bovine proteins, $\beta$-lactoglobulin- $\beta$-casein, $\alpha$-lactalbumin- $\beta$-casein and camel milk proteins $\alpha$-lactalbumin- $\beta$-casein, at air/water interface. Thus, an investigation of the foaming and interfacial behavior of camel proteins mixture $\beta$-casein- $\alpha$-lactalbumin compared to bovine mixtures could be a very useful tool to control and predict the functionality of dairy systems in both milks bovine and camel.

The aim of this work is to examine the foaming and interfacial properties of the camel protein mixtures $\alpha$-lactalbumin- $\beta$-casein by carrying out foam study and transient interfacial measurements and to compare their results to those of bovine mixture systems: $\beta$-casein- $\beta$ lactoglobulin and $\beta$-casein- $\alpha$-lactalbumin, in order to understand the foaming behavior of purified camel milk proteins which can represent an interesting ingredient for food industry.

\section{Material and methods}

\subsection{Single and mixed solution preparation}

Bovine proteins were purchased form Sigma-Aldrich and used without further purification. The purity of $\beta$-casein (Product \#: C6905, Lot \#: SLBH6096V); $\beta$-lactoglobulin (Product \#: L2506, Lot \#: SLBB4325V) and $\alpha$-lactalbumin (Product \#: L5385, Lot \#: SLBJ2493V) are $\geq 98 \%, \geq 85 \%$ and $\geq 85 \%$ respectively.

Camel proteins were purified from camel milk which is purchased from a local herd belonging to a farm in the region of Medenine (Tunisia). Camel milk was collected from 20 different healthy female camels ranging between 2 and 12 months in lactation. Once collected, camel milk was immediately cooled to $4{ }^{\circ} \mathrm{C}$ then transported to the laboratory within 24 hours. $\mathrm{pH}$ values were systematically checked before storing and fat was removed by a centrifugation at $1000 \mathrm{~g}$ during $15 \mathrm{~min}$ at $4{ }^{\circ} \mathrm{C}$ [20].

After defatting, the camel $\alpha$-lactalbumin was purified as described by [21]. Major fractions of caseins and whey proteins of camel milk were precipitated using rennet addition (1.4 ml/l of milk) (M. miehei, strength $=1: 10,000$, Laboratories Arrazi, Parachimic, Sfax, 
Tunisia) [22] then centrifuged at $5000 \mathrm{~g}$ for $20 \mathrm{~min}$ at $20{ }^{\circ} \mathrm{C}$. The supernatant was applied to an UF membrane (cut off $30 \mathrm{kDa}$ ). Purified camel $\alpha$-lactalbumin, was stored at $-20{ }^{\circ} \mathrm{C}$ for further usage.

The camel $\beta$-casein was extracted using the technique described by [23]. Skimmed camel milk samples were warmed to $37{ }^{\circ} \mathrm{C}$. Casein fraction of camel milk was separated from the whey by rennet coagulation as described previously. After centrifugation, the casein curd was kept and a volume of heated demineralized water $\left(80^{\circ} \mathrm{C}\right)$, equal to that of the discarded whey, was added to the curd. The mixture was kept at $80{ }^{\circ} \mathrm{C}$ for $5 \mathrm{~min}$ to enable the action of rennet enzyme using water bath, then centrifuged for $5000 \mathrm{~g}$ for $15 \mathrm{~min}$ at $20{ }^{\circ} \mathrm{C}$. The supernatant was discarded and the curd was mancreated and suspended in demineralized water $\left(5{ }^{\circ} \mathrm{C}\right)$. The suspension was kept at $5^{\circ} \mathrm{C}$ for up to $24 \mathrm{~h}$ and centrifuged at $5000 \mathrm{~g}$ for $15 \mathrm{~min}$ at $5^{\circ} \mathrm{C}$.

The supernatant containing the camel $\beta$-casein was also stored for further analyses.

The purity of the extracted camel $\alpha$-lactalbumin $(>90 \%)$ and $\beta$-casein $(>60 \%)$ was checked by SDS page and HPLC [24,25].

Experiments were carried out in $20 \mathrm{mM}-\mathrm{Tris}-\mathrm{HCl}$ buffer, $\mathrm{pH} 7$ [11]. The $\mathrm{pH}$ was chosen to correspond approximately to milk conditions and the adopted buffer is commonly used to control the $\mathrm{pH}$ in similar interfacial studies.

Proteins were studied individually and in mixture with different ratios chosen according to $[15,26]$.

For all the experiments the following proportions were respected:

- Mixture 1(M1): bovine $\alpha$-lactalbumin- $\beta$-casein, ratio in mixed systems was 0:100 (pure bovine $\alpha$-lactalbumin), 25:75, 50:50, 75:25 and 100:0 (pure bovine $\beta$-casein).

- Mixture 2 (M2): camel $\alpha$-lactalbumin- $\beta$-casein ratios: 0:100 (pure camel $\alpha$ lactalbumin), 25:75, 50:50, 75:25 and 100:0 (pure camel $\beta$-casein).

- Mixture 3 (M3): bovine $\beta$-lactoglobulin- $\beta$-casein at different protein ratios: 0:100 (pure bovine $\beta$-lactoglobulin), 25:75, 50:50, 75:25 and 100:0 (pure bovine $\beta$-casein).

In all samples the total amount of protein (pure/mixed) was $0.5 \mathrm{~g} / \mathrm{l}$ for foaming properties and $0.01 \mathrm{~g} / \mathrm{l}$ for interfacial properties.

\subsection{Foaming studies}

Ten milliliters of the protein solution at a concentration of $0.5 \mathrm{~g} / \mathrm{l}$ dissolved in the Tris$\mathrm{HCl}$ buffer (20mM, pH 7) [11] were introduced in a measuring cylinder (radius $2 \mathrm{~cm}$ and length $8.5 \mathrm{~cm}$ ) then mixed by the Ultra Turrax T25 mixer (IKA Labortechnik, Staufen Germany) at $13500 \mathrm{rpm}$ for $2 \mathrm{~min}$ at room temperature. 
After whipping the protein solution, the volume of foam was systematically measured precisely as function of time.

The foam capacity (FC) in \%, is defined through equation (1)

$\mathrm{FC}=\left(\mathrm{V}_{\text {foam }} / \mathrm{V}_{0}\right) \times 100(1)$

where $\mathrm{V}_{\text {foam }}$ is the volume of the formed foam and $\mathrm{V}_{0}$ the initial volume before creating foam.

Foam stability (FS) is defined as the foam half time or the time for drainage of the half of the initially entrapped liquid in the foam $\left(\mathrm{t}_{\text {foam } 1 / 2}\right)[14]$.

\subsection{Interfacial tension}

Dynamic surface tension measurements were performed with a drop tensiometer (IT Concept, Longessaigne, France). An axisymmetric air drop was formed at the tip of the needle of a syringe plunged in the curve containing protein solution and driven by a computer. The image of the drop was taken from a camera and digitized. The interfacial tension was calculated by analyzing the profile of the created air drop according to Laplace equation (2) :

$$
(1 / x)[d(x \sin \theta) / d x]=(2 / b)-c z,(2)
$$

where $\mathrm{x}$ and $\mathrm{z}$ are the cartesian coordinates at any point of the drop surface, $\theta$ is the angle of the tangent to the drop profile, $b$ is the radius of curvature of the drop apex and $c$ is the capillary constant $(\mathrm{c}=\mathrm{g} \Delta \rho / \gamma$, where $\mathrm{g}$ the acceleration of gravity, $\Delta \rho$ the difference between the densities of the two phases which are separated by the interface of the drop, and $\gamma$ the surface tension).

The control unit can also plot and record the sinusoidal changes of $\gamma$ as a function of time by making the volume of the drop changed at a chosen frequency and amplitude to measure the viscoelastic modulus $(\varepsilon)$ of the surface as defined by the followed equation ( 3$)$ :

$$
|\varepsilon|=\mathrm{d} \gamma / \mathrm{d} \ln \mathrm{A}, \quad(3)
$$

where A is the surface area of the created air drop.

All the surface tension tests were done after controlling the temperature of the apparatus. Indeed, temperature was controlled by water circulation from a thermostat and experiments were carried out at $20 \pm 0.1{ }^{\circ} \mathrm{C}$.

The measurement of the interfacial tension $(\gamma)$ and the viscoelastic modules $(\varepsilon)$ were carried for camel and bovine protein solution at individual or binary mixtures as mentioned in 
section 2.1 . The total concentration of the protein solution was usually adjusted to $10 \mathrm{mg} / \mathrm{l}$, after dilution using Tris- $\mathrm{HCl}$ buffer $\mathrm{pH} 7$ to explain the competitive adsorption behavior of the protein solution at the air/water interface [27].

\subsection{Statistics}

All experiments were carried out in triplicate and reported as the mean \pm one standard deviation. A three-way analysis of variance (ANOVA) was performed to test for significance in the main effects of type (camel and bovine $\beta$-casein and $\alpha$-lactalbumin; $\beta$-lactoglobulin), and protein binary mixture (M1; M2 and M3) along with their associated interactions on the foaming, interfacial tension and viscoelastic modulus measurements.

Statistical analyses were performed with IBM SPSS statistics software (Version 19, IBM SPSS, USA).

\section{Results and discussion}

\subsection{Foaming and interfacial properties for pure bovine and camel protein:}

\subsubsection{Foaming properties of pure protein systems}

Foaming properties (foam capacity and foam stability) of pure bovine proteins $\beta$ lactoglobulin, $\beta$-casein and $\alpha$-lactalbumin and the bovine counterparts ( $\beta$-casein and $\alpha$ lactalbumin) at a concentration of $0.5 \mathrm{~g} / \mathrm{l}$ at $\mathrm{pH} 7$ without further modification are shown in Fig. 1.A and B.

Fig 1. A shows that, as expected, the $\beta$-casein was found to give better foam regardless of the milk origin when compared to $\alpha$-lactalbumin and $\beta$-lactoglobulin, reaching an FC value $\sim 130 \%$. Besides The $\beta$-lactoglobulin was found coat air bubbles better than $\alpha$-lactalbumin (FC $\sim 90 \%$ ). However, no significant difference was found between camel and bovine $\alpha-$ lactalbumin $(\mathrm{FC} \sim 50 \%)$. In agreement with [28] who reported that the $\beta$-casein is considered as the most surface-active protein due to its unordered structure and its high mean residue hydrophobicity. Whereas, both $\alpha$-lactoglobulin and $\beta$-lactalbumin are well known by their considerable amount of $\alpha$-helix, $\beta$-sheet, and intra-molecular disulfide bonds. Besides, their hydrophobic residues are buried in the protein molecule. Consequently, more energy is needed to unfold the protein native structure and longer time is taken to fully adsorb at an air/water interface when creating foams as compared with a flexible protein of caseins. Thus, [14] have found that foaming properties of the flexible $\beta$-casein and the globular $\beta$ lactoglobulin depended closely not only on protein structure but also on the $\mathrm{pH}$ value, $\beta$ casein foamed better at a concentration of $0.1 \mathrm{wt} \%$, when the $\mathrm{pH}$ is above neutral. However, at 
acid $\mathrm{pH}(4-5), \beta$-lactoglobulin foamed better than the $\beta$-casein due to the further reduction of electrostatic repulsion between proteins.

The foaming stability (FS) values of pure proteins at a concentration of $0.5 \mathrm{~g} / \mathrm{l}$ are given in Fig. 1.B. The $\beta$-casein gave the highest stability of foams reaching $1200 \mathrm{~s}$ for bovine $\beta$ casein and $660 \mathrm{~s}$ for the camel counterpart. FS values of $\beta$-casein was found to be significantly higher than that of $\beta$-lactoglobulin ( FS $=450 \mathrm{~s}$ ) and $\alpha$-lactalbumin. Indeed, foams made with camel and bovine $\alpha$-lactalbumin solutions were found to be unstable (FC < $30 \mathrm{~s})$. In agreement with [29] who reported that the $\alpha$-lactalbumin is a small protein that has good foaming properties but poor ability to stabilize the foam created. Thus, it migrates easily at the interface due to its low molecular weight $(14 \mathrm{kDa})$ but it is unable to preserve the consistence of the created film. However for caseins different mechanism was suggested: Casein adsorption layers are denser and thicker and can ensure better stabilization [14].

\subsubsection{Interfacial properties of pure proteins systems}

Interfacial tension and viscoelastic modulus for pure camel and bovine $\alpha$-lactalbumin, $\beta$-casein and $\beta$-lactoglobulin adsorbed at the air/water interface were measured for concentrations $10 \mathrm{mg} / \mathrm{l}$ at $\mathrm{pH} 7$ and they are shown in Fig. $2 \mathrm{~A}$ and $\mathrm{B}$, respectively. Indeed, interfacial tension $\gamma(\mathrm{t})$ is expected to be a main determining factor for the foamability and a faster rate of surface tension decreasing reflects a faster adsorption rate of proteins and a better air bubbles stabilization against coalescence [14].

As shown in Fig. 2.A, changes in $\gamma(\mathrm{t})$ developed by $\beta$-casein were rapid processes, which could be divided into two different stages as found by [30]: a rapid decrease happening during the first 500s followed by a stabilization of the interfacial tension value. The fast reduction of $\gamma(\mathrm{t})$ was observed from approximately $70 \mathrm{mN} / \mathrm{m}$ down to 51.2 and $48.2 \mathrm{mN} / \mathrm{m}$ in $500 \mathrm{~s}$ for bovine and camel $\beta$-casein respectively. At $\mathrm{t}=3600 \mathrm{~s}$, the order of effectiveness was camel $\beta$-casein $(\gamma=44.8 \pm 0.5 \mathrm{mN} / \mathrm{m})>$ bovine $\beta$-casein $(\gamma=48.7 \pm 0.1 \mathrm{mN} / \mathrm{m})>\beta$ lactoglobulin $(\gamma=52.9 \pm 0.8 \mathrm{mN} / \mathrm{m})>$ camel $\alpha$-lactalbumin $(\gamma=57.8 \pm 0.6 \mathrm{mN} / \mathrm{m})=$ bovine $\alpha-$ lactalbumin $(\gamma=58.6 \pm 1.0 \mathrm{mN} / \mathrm{m})$, leading us to conclude that both $\beta$-caseins, in native form, were much more surface active $(\mathrm{p}<0.05)$ than the $\alpha$-lactalbumin and the $\beta$-lactoglobulin.

Thus, [15] reported that the $\beta$-casein is more efficient in reducing interfacial tension than the $\beta$-lactoglobulin at concentrations greater than $10^{-4} \mathrm{~g} / \mathrm{l}$. This behavior was explained by the random, flexible molecular structure of the $\beta$-casein in solution, which, as opposed to 
the globular nature of the $\beta$-lactoglobulin, allows it to decrease the interfacial tension more rapidly over the first minutes compared to the $\beta$-lactoglobulin $[15,19]$.

At $\mathrm{pH}$ 6.7, the $\beta$-lactoglobulin exists as a dimer held together by non-covalent interactions. Each monomer contains two intramolecular disulfide bonds and a free hidden negative sulfhydryl group so the $\beta$-lactoglobulin has a considerable ordered secondary structure and a compact tertiary structure. Consequently, it was not completely unfolded at the interface and the rate of lowering of interfacial tension was less compared to the $\beta$ - casein which can be considered as a mobile disordered molecule [30].

The more important efficiency of the camel $\beta$-casein in reducing the interfacial tension $\gamma(\mathrm{t})$ as compared to the bovine $\beta$-casein is suggested to be due to the difference in aminoacid residues composition between these proteins. Hence, the camel $\beta$-casein contains higher amount of hydrophobic residues such as Ile whose percentage $(5.55 \%)$ is significantly higher when compared to the bovine $\beta$-casein (4.12\%) [31]. Moreover, among camel caseins, the $\beta$ casein is the most hydrophobic casein [32]. The surface tension value of the camel and bovine $\alpha$-lactalbumine are in agreement with [27] who reported that surface tension, already measured at air/water interface of bovine $\alpha$-lactalbumin solution in previous studies (at a concentration of $10^{-3} \%(\mathrm{w} / \mathrm{w})$ and $\left.\mathrm{pH} 8\right)$, achieved a value of $57 \mathrm{mN} / \mathrm{m}$ within an hour.

Fig. 2 B showed the variation of the viscoelastic modulus $\varepsilon$ developed by film made from pure bovine and camel proteins $\beta$-casein, $\alpha$-lactalbumin, and $\beta$-lactoglobulin, as a function of time at $20^{\circ} \mathrm{C}$ during one hour. Depending on the surface active nature and the origin milk of the protein, the magnitude of $\varepsilon(\mathrm{t})$ values varied significantly.

Using $\beta$-casein, regardless of its origin, led immediately to the final and the lowest $\varepsilon$ value from $\mathrm{t}=500 \mathrm{~s}$ as compared to the other proteins. At $\mathrm{t}=3600 \mathrm{~s}$, the order of effectiveness was $\beta$-lactoglobulin $(\varepsilon=50.3 \pm 1.7 \mathrm{mN} / \mathrm{m})>$ bovine $\alpha$-lactalbumin $(\varepsilon=38.1 \pm$ $2.1 \mathrm{mN} / \mathrm{m})>$ camel $\alpha$-lactalbumin $(\varepsilon=26.7 \pm 1.5 \mathrm{mN} / \mathrm{m})>$ bovine $\beta$-casein $(\varepsilon=13.25 \pm 1.7$ $\mathrm{mN} / \mathrm{m})=$ camel $\beta$-casein $(\varepsilon=13.70 \pm 1.1 \mathrm{mN} / \mathrm{m})$. So, we can suggest that the rigidity of the surface film was the lowest for the $\beta$-casein and the highest for the $\beta$-lactoglobulin in agreement with [30].

Thus, the $\beta$-casein exhibited the lowest viscoelastic modulus when compared to globular proteins (Fig. 2B) due to the weaker lateral interactions between the adsorbed molecules which results in a less cohesive and more compressible film. But, the highly viscoelastic character of adsorbed $\beta$-lactoglobulin at the interface would be attributed to a high packing 
density and strong protein-protein connections. It was also suggested that partial unfolding of the $\beta$-lactoglobulin allowed exposure of the sulfhydryl group, which led to slow polymerization of the protein by the interchange between sulfhydryl and disulfide groups in the adsorbed layer [30]. For the $\alpha$-lactalbumin, the adsorbed layer made with the bovine $\alpha$ lactalbumin is more rigid with a higher viscoelastic modulus value than that of the camel $\alpha$ lactalbumin. This behavior suggested that the bovine $\alpha$-lactalbumin can make a stronger protein-protein connection (hydrophobic, hydrogen, and electrostatic interactions) at the air/water interface resulting in more cohesive and rigid film as compared to the camel $\alpha$ lactalbumin.

\subsection{Foaming and interfacial properties for mixed protein systems}

\subsubsection{Foaming properties for mixed protein systems}

Foaming properties for mixed camel and bovine $\alpha$-lactalbumin and $\beta$-casein were measured as a function of the protein weight ratio (see section 2. 2) and are compared in Fig.3. A B. FC values obtained for pure proteins (Fig. 1) with the same total protein concentration used in the mixtures $(0.5 \mathrm{~g} / \mathrm{l})$ are also shown as a reference.

Fig. 3.A shows that both protein mixtures camel and bovine were characterized by an intermediate foaming behavior between those of $\beta$-casein and $\alpha$-lactalbumin alone: the added $\beta$-casein increased significantly the FC value. For bovine mixture: $\mathrm{M} 1$, an increase of $\beta$-casein proportion from $25 \%$ to $75 \%$ (corresponding to systems $\mathrm{M}_{75: 25}$ and $\mathrm{M}_{25: 75}$ respectively) of total protein amount, significantly increased this property with a foam capacity of $\alpha-$ lactalbumin- $\beta$-casein mixture of $137 \%(\mathrm{p}<0.05)$, which represents an increase of $41 \%$. Besides, for camel protein mixture M2: FC value increased significantly $(p<0.05)$ from $88 \%$ to $123 \%$ when $\beta$-casein proportion rose from $25 \%$ to $75 \%$ of the total camel proteins. For bovine protein mixture $\mathrm{M} 3, \mathrm{FC}$ of mixed systems was dominated by the $\beta$-casein. At $\mathrm{pH} 7$, mixed foams showed intermediate values of FC with a significant increase of $46.2 \%$ between pure $\beta$-lactoglobulin (M30:100) to $\mathrm{M} 350: 50$. No significant difference was found between the systems M350:50, M325:75 and M30:100. ( $\mathrm{p}<0.05$ ). In Agreement with [33] who reported that $\beta$ casein is the first adsorbed protein at the interface when compared to other milk proteins. Indeed, $\beta$-casein can be considered as a mobile disordered molecule, because its diffusion is faster than the other milk protein and it remains predominantly at the interface. Besides, when injected into a casein solution, the $\beta$-casein can move $\alpha_{\mathrm{s} 1}$-casein of the interface but the 
reverse behavior is less easy [34]. Caseins which are characterized by a flexible structure display better surface activity and consequently better interfacial properties than those with a rigid structure such as $\beta$-lactoglobulin. The $\beta$-casein, which is the most known flexible milk protein, has a particularly strong amphiphilic character which makes it more effective than both $\beta$-lactoglobulin and whole milk in reducing the surface tension [30]. So, while creating foams or emulsions, $\beta$-casein is always adsorbed over other caseins and caseins over whey proteins. Thus, the processes involving the diffusion, the reorientation and the conformational reorganization of $\beta$-casein at the interface occur faster than that of the $\beta$-lactoglobulin due to the low structuration of $\beta$-casein. It has been found that while creating milk foams, all proteins were found enriched in the foam phase compared to the original milk solution, especially $\beta$-casein which represented the highest ratio. This enrichment of proteins is explained with the bounding of the $\beta$-casein to air/water interface and in the lamellae between air bubbles. This behavior is due to the amphiphilic nature of this protein allowing them to adsorb and concentrate at interfaces [28].

Fig. 3.B shows the half-time of liquid drainage from the foams created by camel and bovine mixtures M1, M2 and M3. The foams generated from the bovine mixed systems M1 and M3 (50:50; 25:75 and 0:100) were more stable than the same mixtures made by the camel proteins. Yet no significant difference was observed between camel and bovine protein mixtures: systems 25:75 and 0:100 ( $\mathrm{p}<0.05)$.

For both systems, the stability of mixed foams increased with increasing $\beta$-casein content. Thus, the foam stability is mainly governed by the $\beta$-casein. The increase in foam stability is due to an increase in the diffusion and adsorption of milk proteins at the surface [12]. Therefore, further studies established that the stability of milk foam increased with an increasing content of $\beta$-casein up to a certain degree and then it remained constant [35].

\subsubsection{Interfacial properties for mixed protein systems}

The interfacial tensions for camel and bovine mixed proteins M1 M2 and M3 were measured as function of time and are compared in fig.3.A,B and $\mathrm{C}$ respectively.

Values already obtained (Fig.2.A) for pure proteins with the same total protein concentration used in the mixtures $(11 \mathrm{mg} / \mathrm{l})$ are also shown as a reference.

Fig.4. (A B C) compares the interfacial tension of bovine and camel $\alpha$-lactalbumin- $\beta$-casein mixture and $\beta$-lactoglobulin- $\beta$-casein at different proportion. The evolution of the surface tension $\gamma(\mathrm{t})$, as a function of time, induced by the different camel $\alpha$-lactalbumin solution was 
characterized by an intermediate adsorption behavior between those of $\alpha$-lactalbumin and $\beta$ casein alone. A greater efficiency to reduce the surface tension was attributed to the mixture with a higher amount of $\beta$-casein. At $t=3600 \mathrm{~s}$, for the bovine mixture M1 (bovine $\alpha$ lactalbumin- $\beta$-casein), the order of effectiveness was: $M 1_{0: 100}(48.7 \pm 0.1 \mathrm{mN} / \mathrm{m})=$ $\mathrm{M}_{25: 75}(48.8 \pm 0.1 \mathrm{mN} / \mathrm{m})>\operatorname{M}_{50: 50}(50.6 \pm 0.1 \mathrm{mN} / \mathrm{m})>\operatorname{M1}_{75: 25}(51.9 \pm 0.1 \mathrm{mN} / \mathrm{m})$ $>\mathrm{M} 1_{100: 0}(58.6 \pm 1.0 \mathrm{mN} / \mathrm{m})$. Besides, as shown in fig.3.B, the order of effectiveness for camel mixture $\mathrm{m} 2$ (camel $\alpha$-lactalbumin- $\beta$-casein) at $\mathrm{t}=3600 \mathrm{~s}$ was: $\mathrm{M} 1_{0: 100}(44.8 \pm 0.5 \mathrm{mN} / \mathrm{m})>$ $M 1_{25: 75}(48.4 \pm 0.5 \mathrm{mN} / \mathrm{m})=\mathrm{M} 1_{50: 50}(47.3 \pm 0.2 \mathrm{mN} / \mathrm{m})>\mathrm{M}_{75: 25}(52.9 \pm 0.1)>\mathrm{M} 1_{100: 0}(58.6 \pm 0.6$ $\mathrm{mN} / \mathrm{m})(\mathrm{p}<0.05)$.

These results lead to note that for $\alpha$-lactalbumin- $\beta$-casein mixtures, regardless of the milk species the interfacial tension varied significantly depending on the $\beta$-casein amount on the protein mixture $(\mathrm{p}<0.05)$. So it can be concluded that for a mixture which contains the $\beta$ casein and the $\alpha$-lactalbumin, the adsorption dynamic is mainly controlled by the $\beta$-casein even if its bulk concentration is lower than that of the $\alpha$-lactalbumin. These findings are in agreement with the highest foam capacity and stability observed with the same solution of $\alpha$ lactalbumin (Fig. 3 A).

For the mixture M3 which contains $\beta$-lactoglobulin and $\beta$-casein, Fig.4 $\mathrm{C}$ shows that protein mixtures are characterized by intermediate interfacial tension behavior between those of $\beta$-lactoglobulin and $\alpha$-casein alone. However, the evolution of surface tension shapes as function of time of $\beta$-lactoglobulin and $\beta$-casein mixtures are very similar. At $t=3600 \mathrm{~s}$, the surface tension value of $\beta$-lactoglobulin $(\gamma=52.91 \pm 0.7 \mathrm{mN} / \mathrm{m})$ was significantly higher than that of bovine $\beta$-casein, but no significant difference was observed between protein mixture M3 and bovine $\beta$-casein $(p<0.05)$. In accordance with the results of [15], done with $\beta$ lactoglobulin- $\beta$-casein mixtures, who reported that the similarity of the equilibrium interfacial tensions values of all the mixtures, to that of $\beta$-casein confirmed the greater presence of this protein at the interface.

Overall, the greater influence of $\beta$-casein with respect to $\beta$-lactoglobulin on the mixture adsorption behavior at the interface is due to its capacity to adsorb more rapidly at the interface and to change its conformation more easily. Consequently, the $\beta$-casein is able to occupy the majority of interfacial sites, wholly or partially replacing $\beta$-lactoglobulin molecules from the interface [15].

Speculative pictorial models of the adsorption layers available from the literature were proposed to explain the foam and interfacial properties of caseins and whey proteins: 
- The $\beta$-casein adsorbed molecules can be represented as two layers according to [36]: the first one is adjacent to the interface, it's inner and dense with a thickness $1-2.5 \mathrm{~nm}$ containing the hydrophobic residues of the $\beta$-casein. The second layer is extending into the aqueous phase, extending 3-7.5nm. It is less dense and composed mostly from the hydrophilic aminoacids of the $\beta$-casein.

- For globular proteins it was observed that adsorbed proteins layer is composed of an intact average of globular protein molecules. The negative charge and the electrostatic repulsion of proteins prevent the formation of a dense adsorbed layer as shown for the $\beta$-casein. [14].

Dynamic viscoelastic modulus was also used to further examine the impact of bovine and camel $\alpha$-lactalbumin- $\beta$-casein (M1 and M2) and also the impact of bovine $\beta$-lactoglobulin- $\beta$ casein (M3) on the rheological properties of the mixed protein interfacial layers adsorbed at the air/water interface. Obtained results are mentioned on Fig. 5. For mixed protein systems: $\alpha$-lactalbumin- $\beta$-casein extracted from bovine and camel milks (Fig. 5 A and B respectively) and $\beta$-lactoglobulin- $\beta$-casein mixture (Fig. $5 \mathrm{C}$ ) with data for pure protein films shown as a reference. Fig. 5 shows that both the magnitude and the general shape of $\varepsilon(\mathrm{t})$ curves were affected depending on the $\beta$-casein amount of protein mixture used as surface active. Fig.5 shows that for all mixtures M1, M2 and M3, it can be noticed that all mixtures exhibited lower viscoelastic modulus $\varepsilon(\mathrm{t})$ than pure $\beta$-lactoglobulin and $\alpha$-lactalbumin. For bovine and camel mixtures $\alpha$-lactalbumin- $\beta$-casein (M1 and M2), no significant difference was observed between viscoelastic modulus values of pure $\beta$-casein except for mixture 75:25 which represent an intermediate viscoelastic modulus between that of $\alpha$-lactalbumin and $\beta$-casein. For bovine mixture M3, no significant difference was observed between viscoelastic modulus values between mixtures and pure $\beta$-casein (M3 0:100). So, it can be concluded that for the protein mixed layers, viscoelastic modulus values are mainly dominated by the $\beta$-casein. However, the $\alpha$-lactalbumin at a higher amount is able to give a rigid protein film at the interface in agreement with [37]. Thus, it has been reported that $\alpha$-lactalbumin adsorbs more slowly but gives a fairly rigid interface.

Besides, viscoelastic modulus was found to increase with decreasing protein flexibility. So, proteins that can adsorb and rearrange quickly at the interfaces, such as the $\beta$-casein, are expected to give a lower dilatational modulus due to the greater flexibility and the more rapid recovery at the interface [15]. 


\section{Conclusion}

The performed systematic foaming tests with camel and bovine proteins: $\alpha$-lactalbumin$\beta$-casein as compared to the mixture $\beta$-lactoglobulin- $\beta$-casein either alone or in binary mixtures was determined to investigate the role of the major proteins in creating foams in both bovine milk and camel milk.

The results obtained in this work indicate that for pure proteins, the $\beta$-casein exhibited the highest foaming properties as compared to globular proteins $\alpha$-lactalbumin and $\beta$ lactoglobulin. Besides, for both bovine and camel studied mixtures, the foamability and foam stability systems changed and increased with the $\beta$-casein amount in protein mixture. Therefore, it can be suggested that the $\beta$-casein plays the main role in creating and stabilizing camel milk foams.

The interfacial properties of camel milk proteins $\beta$-casein, $\alpha$-lactalbumin and $\beta$ lactoglobulin, alone or in binary mixtures at the air/water interface were studied using pendant drop tensiometer.

High correlation was observed between the foaming properties and the surface tension evolution as function of time. Camel and bovine $\beta$-casein were more efficient in reducing the interfacial tension than the globular proteins camel and bovine $\alpha$-lactalbumin and $\beta$ lactoglobulin. This behavior can be explained by the difference of molecule structure between caseins and globular protein.

Interfacial properties of camel and bovine protein mixture approaches evidencing the greater propensity of both $\beta$-caseins camel and bovine, with respect to $\alpha$-lactalbumin and $\beta$ lactoglobulin, to control the adsorption phenomena and rheological behavior of the mixtures. This behavior is probably due to the capacity of $\beta$-casein to adsorb more rapidly at the air/water interface and to change its conformation more easily.

Viscoelastic modulus values were also analyzed to predict the composition of protein layer. They seem to confirm the greater presence of $\beta$-casein at the air water interface with respect to $\alpha$-lactalbumin and $\beta$-lactoglobulin for all the $\beta$-casein mixture ratios M1, M2 and M3 ratios except for the samples containing the highest $\alpha$-lactalbumin at the interface. So, for camel milk, the $\alpha$-lactalbumin seems to be prevalent at the interface even though this effect seems hindered by the $\beta$-casein contribution. 


\section{References}

[1] E.I. El-Agamy, Z. Abou-Shloue, Y.I. Abdel-Kader, Gel electrophoresis of proteins, physicochemical characterization and vitamin $\mathrm{C}$ content of milk of different species, Alexandria J. Agric. Res. 43 (1998) 57-70.

[2] K.I. Ereifej, M.H. Alu'datt, H. A. Alkhalidy, I. Alli, T. Rababah, Comparison and characterisation of fat and protein composition for camel milk from eight Jordanian locations, Food Chem. 127 (2011) 282-289.

[3] S.R. Kappeler, Z. Farah, Z. Puhan, 5'-Flanking regions of camel milk genes are highly similar to homologue regions of other species and can be divided into two distinct groups, J. Dairy Sci. 86 (2003) 498-508.

[4] S. Kappeler, Z. Farah, Z. Puhan, Sequence analysis of Camelus dromedarius milk caseins, J. Dairy Res. 65 (1998) 209-222.

[5] A. Barzegar, R. Yousefi, A. Sharifzadeh, M. Dalgalarrondo, J.M. Chobert, M.R. Ganjali, P. Norouzi, M.R. Ehsani, A. Niasari-Naslaji, A.A. Saboury, T. Haertlé, A.A. Moosavi-Movahedi, Chaperone activities of bovine and camel $\beta$-caseins: Importance of their surface hydrophobicity in protection against alcohol dehydrogenase aggregation, Int. J. Biol. Macromol. 42 (2008) 392-399.

[6] L.C. Laleye, B. Jobe, A.A.H. Wasesa, Comparative study on heat stability and functionality of camel and bovine milk whey proteins, J. Dairy Sci. 91 (2008) 45274534.

[7] U. Merin, S. Bernstein, R. Yagil, C. Van Creveld, P. Lindner, N. Gollop, Short communication A comparative study of milk serum proteins in camel (Camelus dromedarius) and bovine colostrum, Livest. Prod. Sci. 67 (2001) 297-301.

[8] A. Omar, N. Harbourne, M.J. Oruna-Concha, Quantification of major camel milk proteins by capillary electrophoresis, Int. Dairy J. (2016) 1-5.

[9] H. El-Hatmi, J.M. Girardet, J.L. Gaillard, M.H. Yahyaoui, H. Attia, Characterisation of whey proteins of camel (Camelus dromedarius) milk and colostrum, Small Rumin. Res. 70 (2007) 267-271.

[10] O.U. Beg, H. von Bahr-Lindström, Z.H. Zaidi, H. Jörnvall, The primary structure of alpha-lactalbumin from camel milk., Eur. J. Biochem. 147 (1985) 233-239.

[11] M.S. Atri, A.A. Saboury, R. Yousefi, J. Chobert, T. Haertle, A.A. Moosavi-Movahedi, Comparative study on heat stability of camel and bovine apo and holo $\alpha$-lactalbumin, J. Dairy Res. 77 (2010) 43-49.

[12] E. Dickinson, Hydrocolloids at interfaces and the influence on the properties of dispersed systems, Food Hydrocoll. 17 (2003) 25-39. 
[13] K. Borcherding, P.C. Lorenzen, W. Hoffmann, K. Schrader, Effect of foaming temperature and varying time/temperature-conditions of pre-heating on the foaming properties of skimmed milk, Int. Dairy J. 18 (2008) 349-358.

[14] K.G. Marinova, E.S. Basheva, B. Nenova, M. Temelska, A.Y. Mirarefi, B. Campbell, I.B. Ivanov, Physico-chemical factors controlling the foamability and foam stability of milk proteins : Sodium caseinate and whey protein concentrates, Food Hydrocoll. 23 (2009) 1864-1876.

[15] L. Seta, N. Baldino, D. Gabriele, F.R. Lupi, B. De Cindio, Rheology and adsorption behaviour of $\beta$-casein and $\beta$-lactoglobulin mixed layers at the sunflower oil/water interface, Colloids Surfaces A Physicochem. Eng. Asp. 441 (2014) 669-677.

[16] S. Rouimi, C. Schorsch, C. Valentini, S. Vaslin, Foam stability and interfacial properties of milk protein-surfactant systems, Food Hydrocoll. 19 (2005) 467-478.

[17] E. Dickinson, Milk protein interfacial layers and the relationship to emulsion stability and rheology, Colloids Surfaces B Biointerfaces. 20 (2001) 197-210.

[18] B.E. Brooker, M. Anderson, A.T. Andrews, The development of structure in whipped cream, Food Struct. 5 (1986) 12.

[19] R. Wüstneck, J. Krägel, R. Miller, V.B. Fainerman, P.J. Wilde, D.K. Sarker, D.C. Clark, Dynamic surface tension and adsorption properties of $\beta$-casein and $\beta$ lactoglobulin, Food Hydrocoll. 10 (1996) 395-405.

[20] S.R. Kappeler, M. Ackermann, Z. Farah, Z. Puhan, Sequence analysis of camel (Camelus dromedarius) lactoferrin, Int. Dairy J. 9 (1999) 481-486.

[21] M. Salami, R. Yousefi, M. Reza, S. Hadi, J. Chobert, A. Akbar, M. Sadat, A. NiasariNaslaji, F. Ahmad, T. Haertle, A.A. Moosavi-Movahedi, Enzymatic digestion and antioxidant activity of the native and molten globule states of camel $\alpha$-lactalbumin: Possible significance for use in infant formula, Int. Dairy J. 19 (2009) 518-523.

[22] I. Felfoul, C. Lopez, F. Gaucheron, H. Attia, M. A. Ayadi, A laboratory investigation of cow and camel whey proteins deposition under different heat treatments, Food Bioprod. Process. 96 (2015) 256-263.

[23] T. Huppertz, J.B. Hennebel, T. Considine, Shakeel-Ur-Rehman, A.L. Kelly, P.F. Fox, A method for the large-scale isolation of $\beta$-casein, Food Chem. 99 (2006) 45-50.

[24] U.K. Laemmli, Cleavage of structural proteins during the assembly of the head of bacteriophage T4, Nature. 227 (1970) 680-685.

[25] G. Bobe, D.C. Beitz, a. E. Freeman, G.L. Lindberg, Separation and quantification of bovine milk proteins by reversed-phase high-performance liquid chromatography, J. Agric. Food Chem. 46 (1998) 458-463. 
[26] M.J. Martinez, C. Carrera Sánchez, J.M. Rodríguez Patino, A.M.R. Pilosof, Interactions between $\beta$-lactoglobulin and casein glycomacropeptide on foaming, Colloids Surfaces B Biointerfaces. 89 (2012) 234-241.

[27] E. Ibanoglu, Ş. Ibanoglu, Foaming behaviour of EDTA-treated $\alpha$-lactalbumin, Food Chem. 66 (1999) 477-481.

[28] Z. Zhang, D.G. Dalgleish, H.D. Goff, Effect of $\mathrm{pH}$ and ionic strength on competitive protein adsorption to air / water interfaces in aqueous foams made with mixed milk proteins, Colloids Surfaces B Biointerfaces. 34 (2004) 113-121.

[29] A.W. Slack, C.H. Amundson, C.G. Hill, Foaming and emulsifying characteristics of fractionated whey protein, J. Food Process. Preserv. 10 (1986) 81-88.

[30] E. Cases, C. Rampini, P. Cayot, Interfacial properties of acidified skim milk, J. Colloid Interface Sci. 282 (2005) 133-141.

[31] S.H. Salmen, H.M. Abu-Tarboush, A.A. Al-Saleh, A.A. Metwalli, Amino acids content and electrophoretic profile of camel milk casein from different camel breeds in Saudi Arabia, Saudi J. Biol. Sci. 19 (2012) 177-183.

[32] M. Salami, A.A. Moosavi-Movahedi, F. Moosavi-Movahedi, M.R. Ehsani, R. Yousefi, M. Farhadi, A. Niasari-Naslaji, A.A. Saboury, J.-M. Chobert, T. Haertlé, Biological activity of camel milk casein following enzymatic digestion, J. Dairy Res. 78 (2011) 471-478.

[33] E. Dickinson, Proteins at interfaces and in emulsions Stability, rheology and interactions, J. Chem. Soc. Faraday Trans. 94 (1998) 1657-1669.

[34] E.W. Robson, D.G. Dalgleish, Interfacial composition of sodium caseinate emulsions, J. Food Sci. 52 (1987) 1694-1698.

[35] M. Anderson, B.E. Brooker, E. Dickinson, G. Stainsby, Dairy foams., Adv. Food Emuls. Foam. (1988) 221-255.

[36] E. Dickinson, D.S. Horne, J.S. Phipps, R.M. Richardson, A neutron reflectivity study of the adsorption of beta-casein at fluid interfaces, Langmuir. 9 (1993) 242-248.

[37] M. Mellema, J.G. Isenbart, Effect of acidification and heating on the rheological properties of oil-water interfaces with adsorbed milk proteins., J. Dairy Sci. 87 (2004) 2769-2778. 


\section{Lajnaf et al.}

Fig. 1. Foam capacity: FC (A) and foam stability: FS (B) of pure proteins systems: camel and bovine $\alpha$-lactalbumin $(\alpha$-lac), camel and bovine $\beta$-casein ( $\beta$-cas) and $\beta$-lactoglobulin $(\beta$ - $\mathrm{Lg})$, at a concentration of $0.5 \mathrm{~g} / \mathrm{l}, \mathrm{pH} 7$ and temperature $20^{\circ} \mathrm{C}$.

${ }^{a-d}$ Samples represented with different letters are significantly different from each other $(p<0.05)$. Error bars show the variations of three determinations in terms of standard deviation of mean.

Fig. 2. Time-dependent changes in interfacial tension $\gamma(\mathrm{A})$ and viscoelastic modulus $\varepsilon(\mathrm{B})$ at air/water interface of pure proteins systems: camel and bovine $\alpha$-lactalbumin $(\alpha$-lac), camel and bovine $\beta$-casein ( $\beta$-cas) and $\beta$-lactoglobulin $(\beta-\mathrm{Lg})$, at a concentration of $10 \mathrm{mg} / \mathrm{l}, \mathrm{pH} 7$ and temperature $20^{\circ} \mathrm{C}$.

Fig. 3. Overall Foam Capacity: FC (A) and Foam Stability: FS (B) for foams generated from aqueous solutions of three protein mixture systems: bovine $\alpha$-lactalbumin- $\beta$-casein M1 (white bars), camel $\alpha$-lactalbumin- $\beta$-casein M2 (grey bars) and $\beta$-lactpglobulin- $\beta$-casein M3 (black bars). Total protein concentration: $0.5 \mathrm{~g} / \mathrm{l}, \mathrm{pH} 7$ and temperature $20^{\circ} \mathrm{C}$.

${ }^{\mathrm{a}-\mathrm{e}}$ Samples represented with different letters are significantly different from each other. Error bars are standard deviations of mean values of duplicates. Mean values with different letters was significantly different $(\mathrm{p}<0.05)$.

Fig. 4. Transient interfacial tension $\gamma$ at the air/water interface as function of time of three proteins mixture systems: bovine $\alpha$-lactalbumin- $\beta$-casein: M1 (A), camel $\alpha$-lactalbumin- $\beta$ casein : M2 (B) and $\beta$-lactpglobulin- $\beta$-casein: M3 (C). Total protein bulk concentration: 10 $\mathrm{mg} / \mathrm{l}, \mathrm{pH} 7$ and temperature $20^{\circ} \mathrm{C}$.

Fig. 5. Viscoelastic modulus $\varepsilon$ at the air/water interface as function of time of three proteins mixture systems: bovine $\alpha$-lactalbumin- $\beta$-casein M1 (A), camel $\alpha$-lactalbumin- $\beta$-casein M2 (B) and $\beta$-lactpglobulin- $\beta$-casein M3 (C). Total protein bulk concentration: $10 \mathrm{mg} / \mathrm{l}, \mathrm{pH} 7$ and temperature $20^{\circ} \mathrm{C}$. 

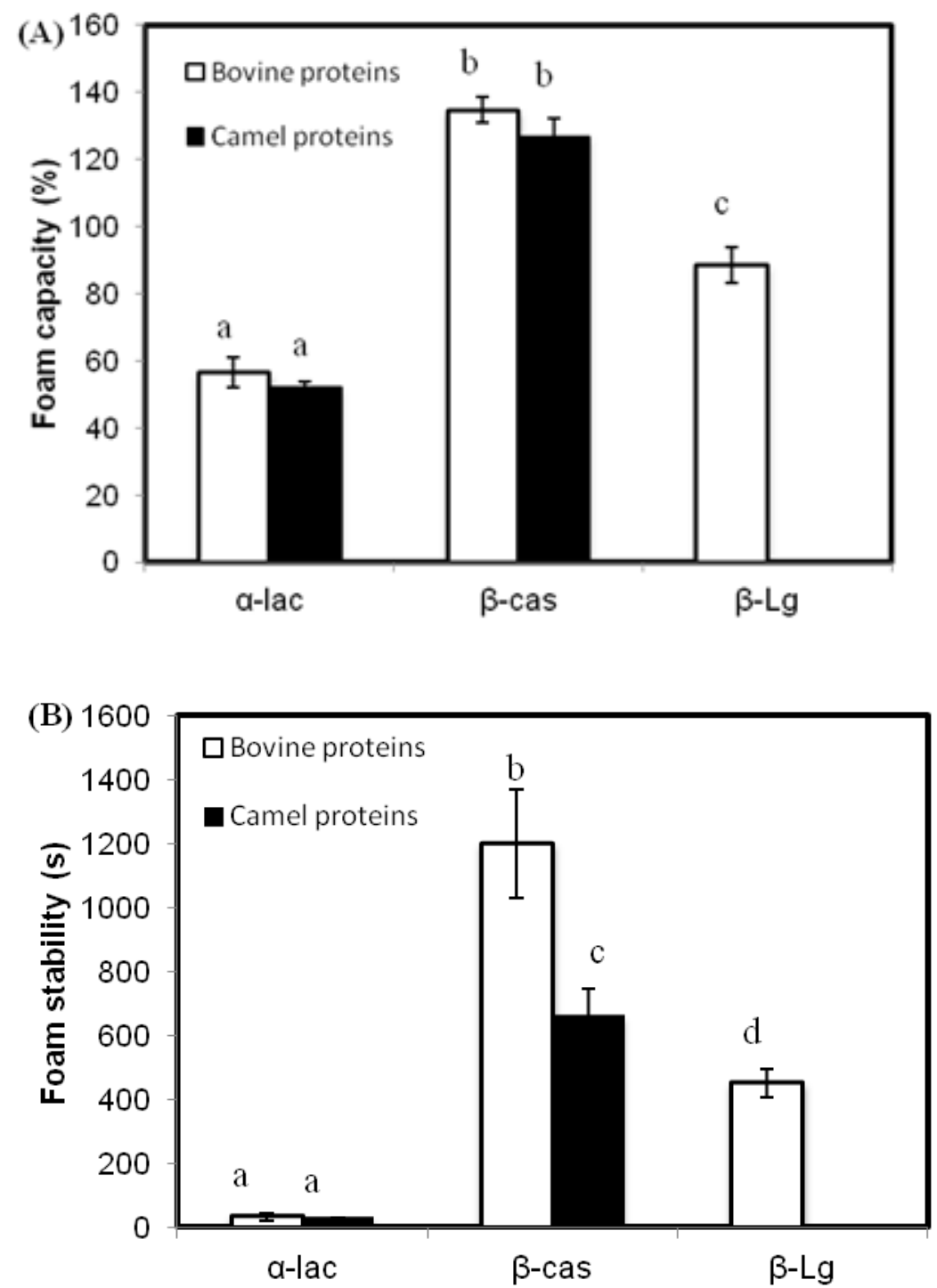

Fig. 1 


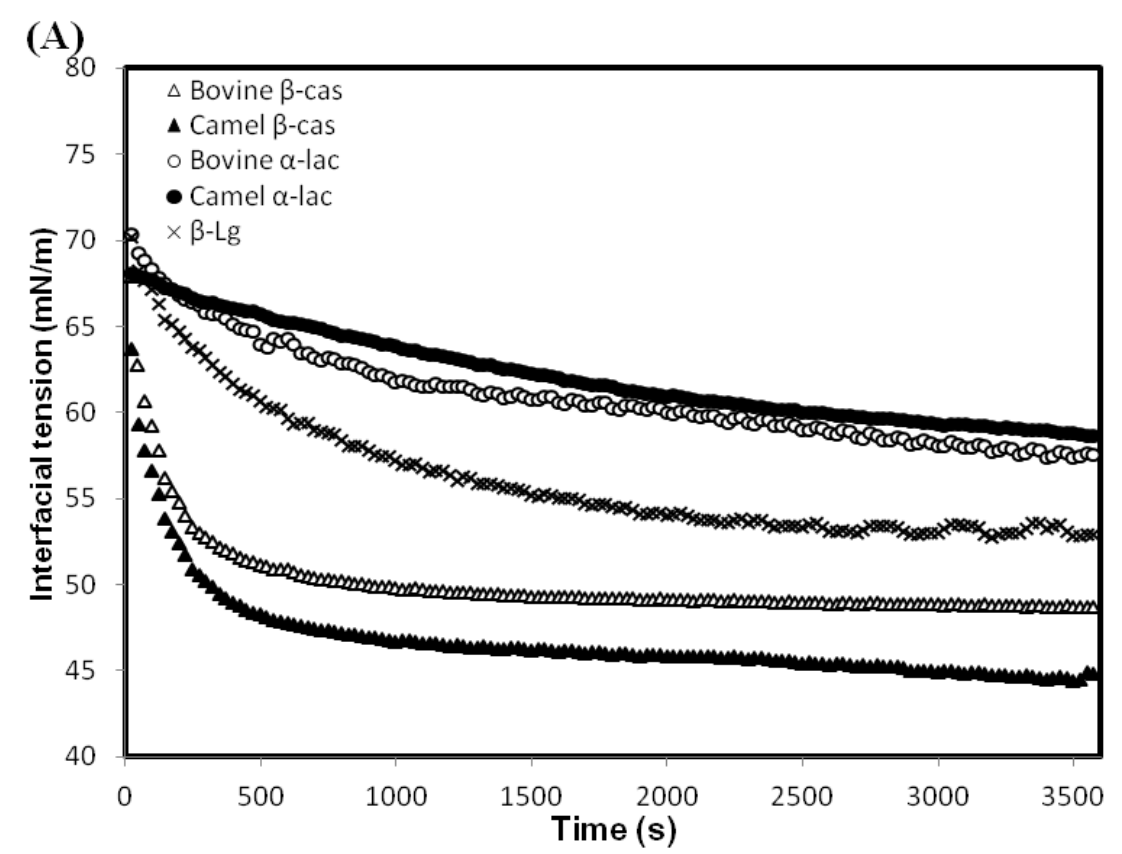

(B)

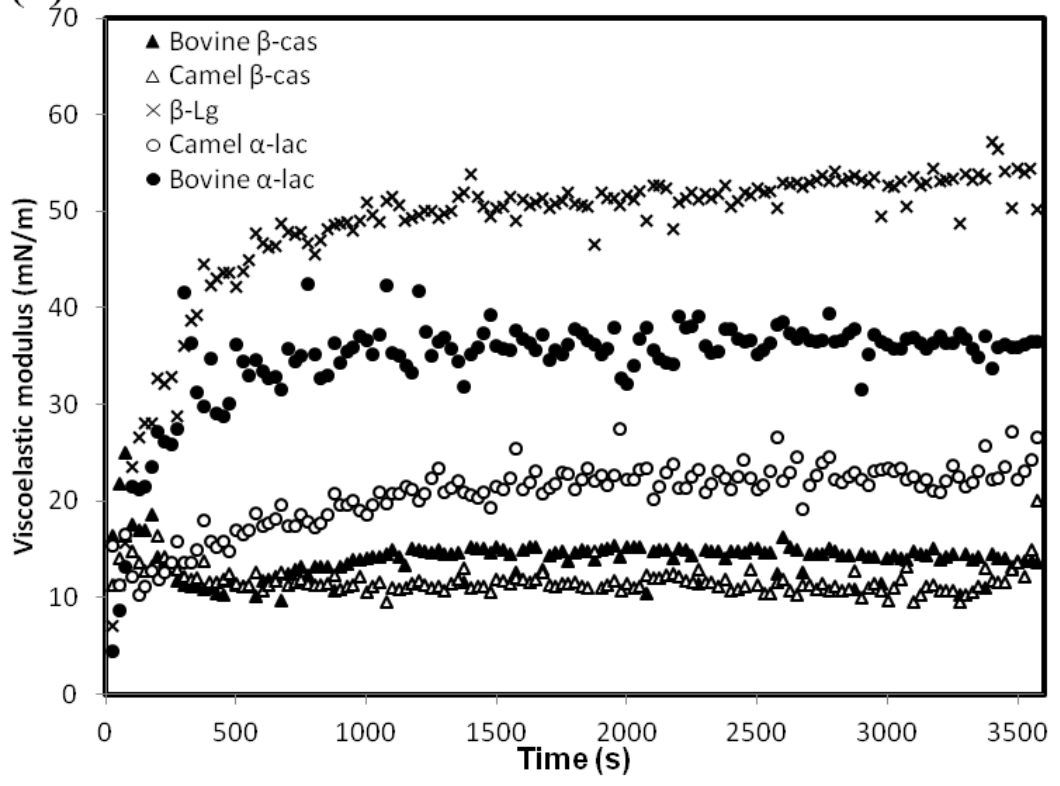

Fig. 2 

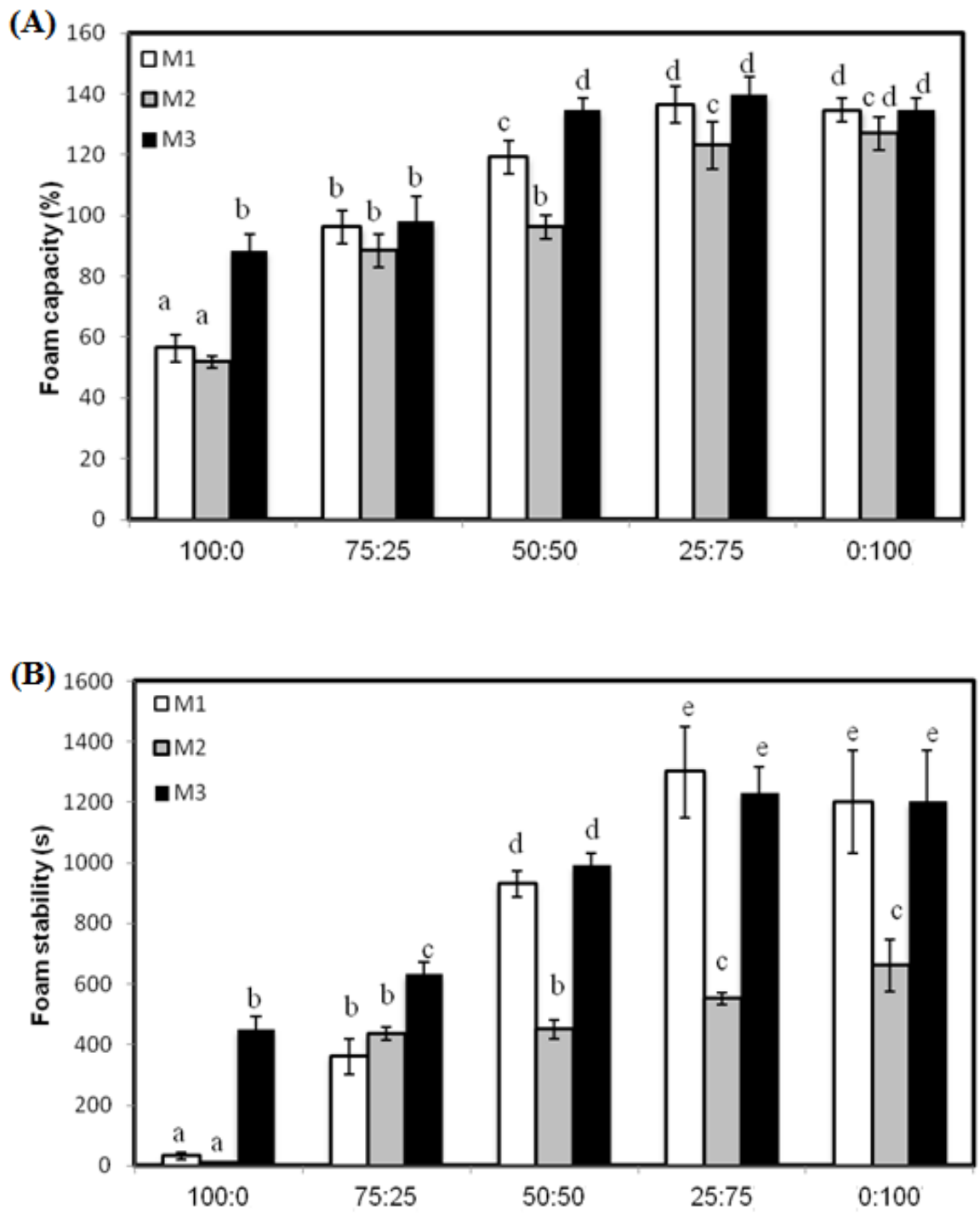

Fig. 3 

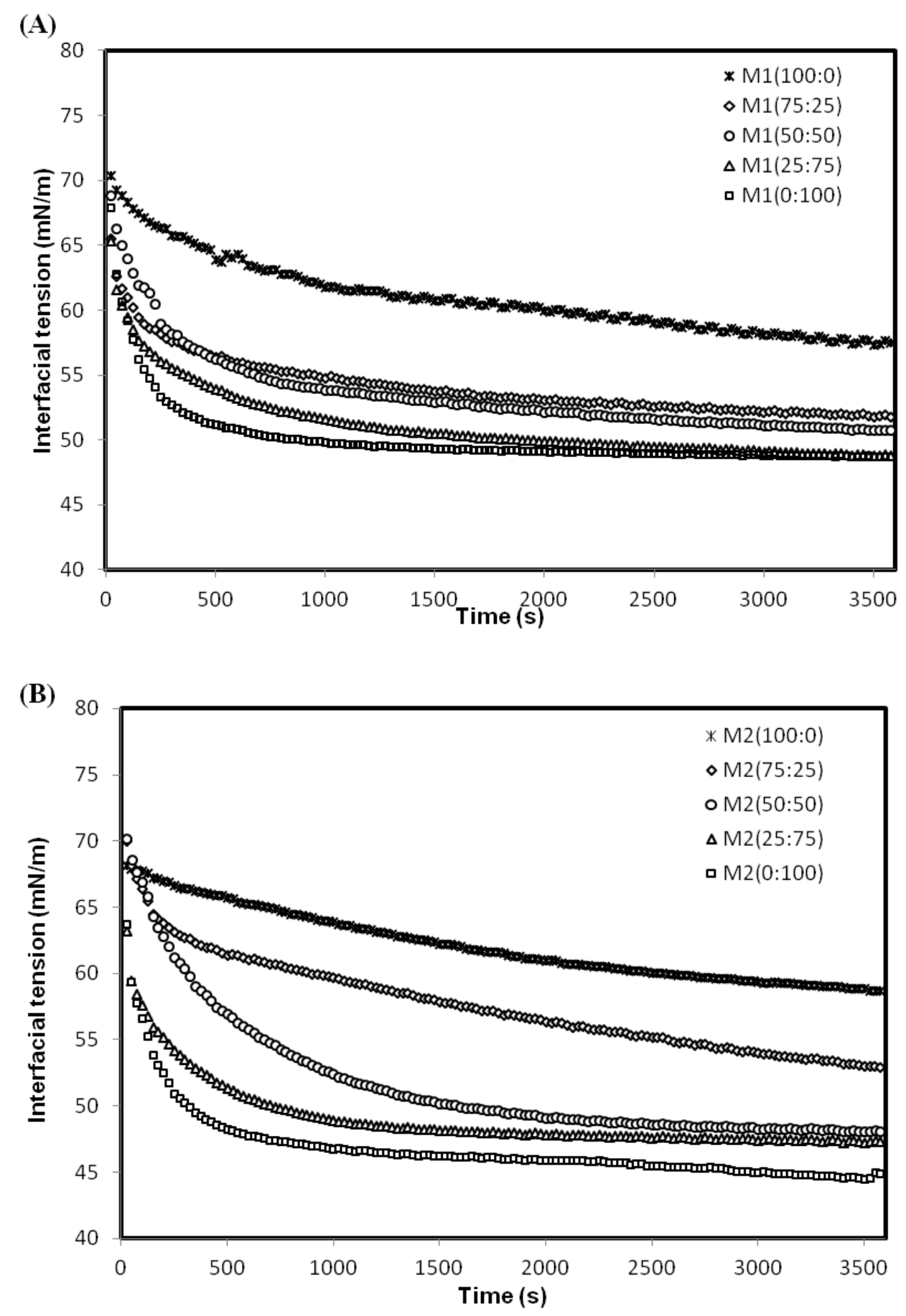


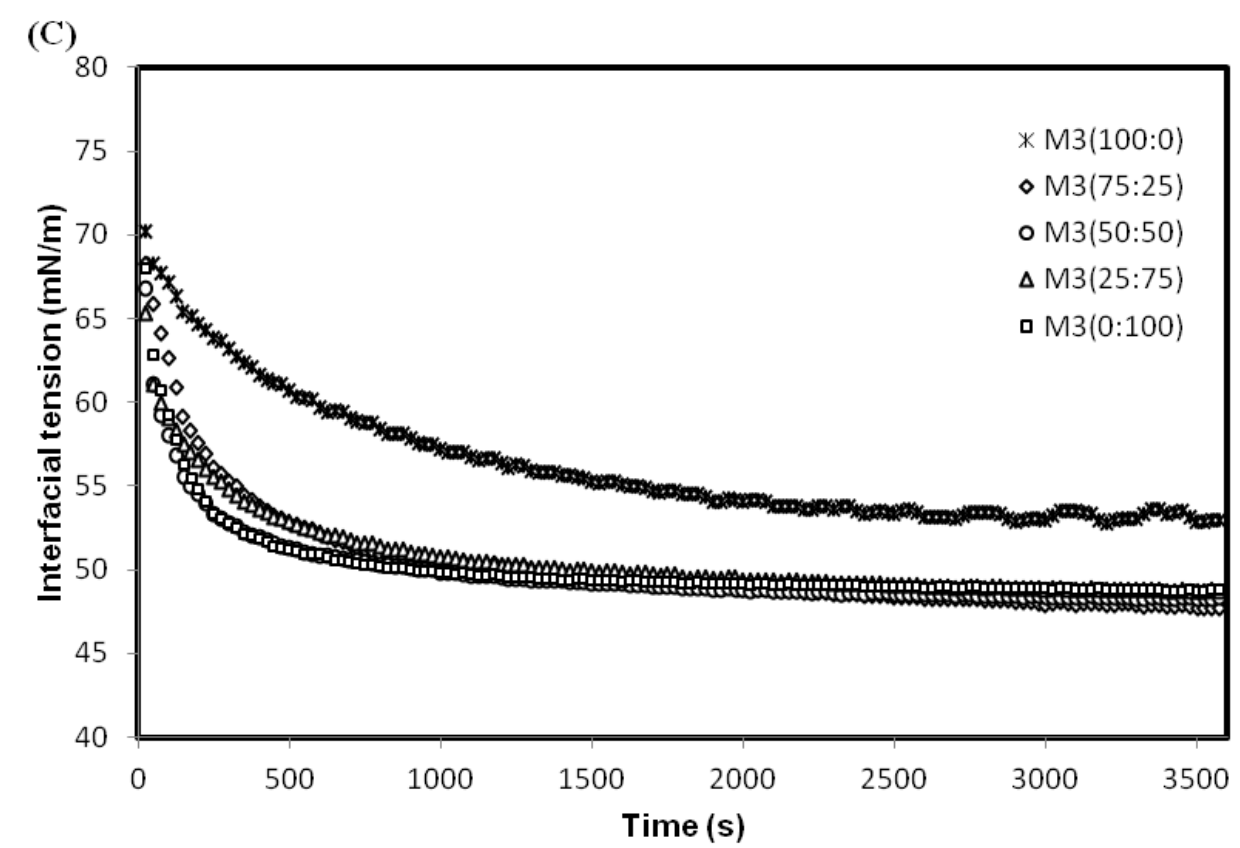

Fig. 4 

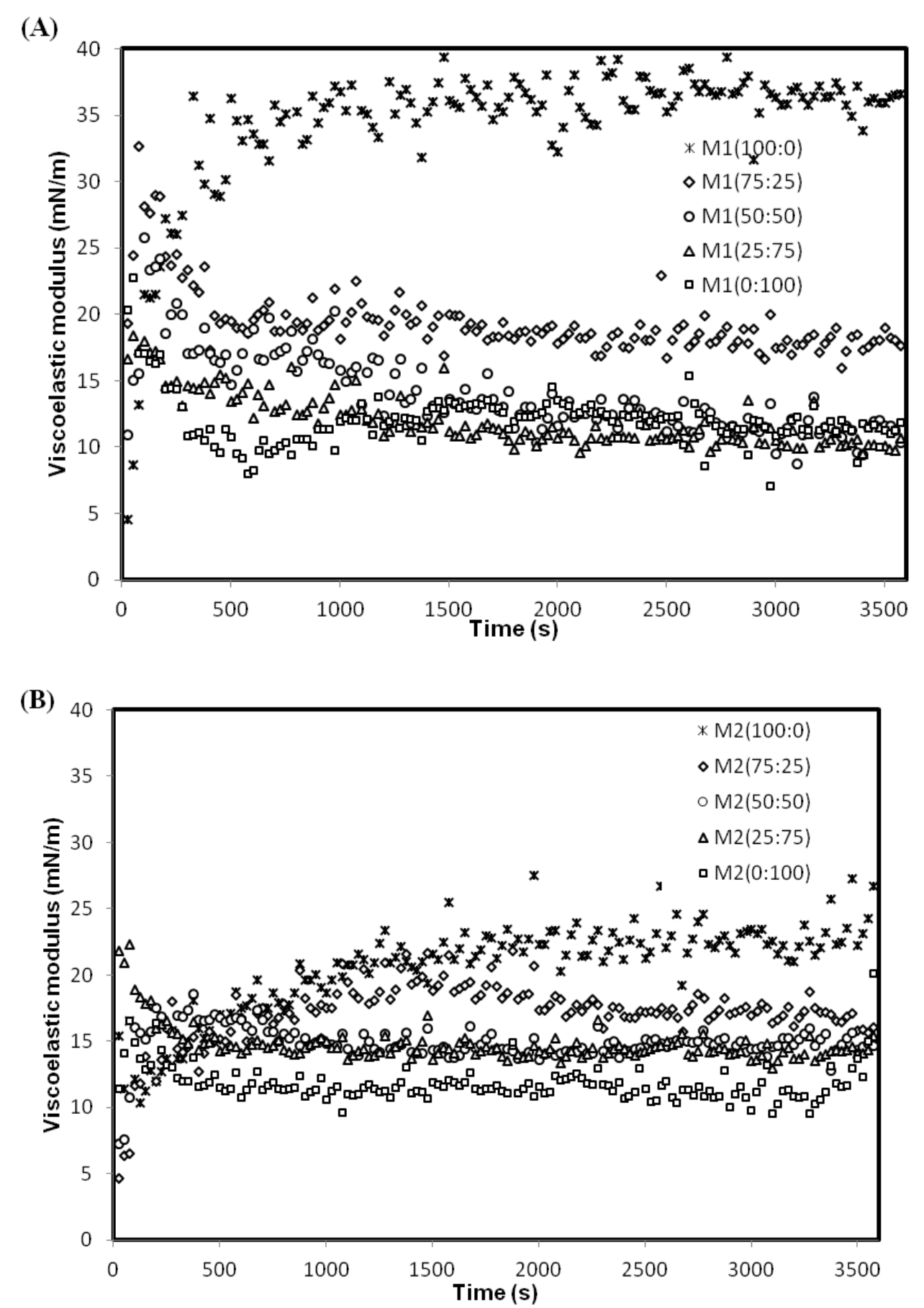


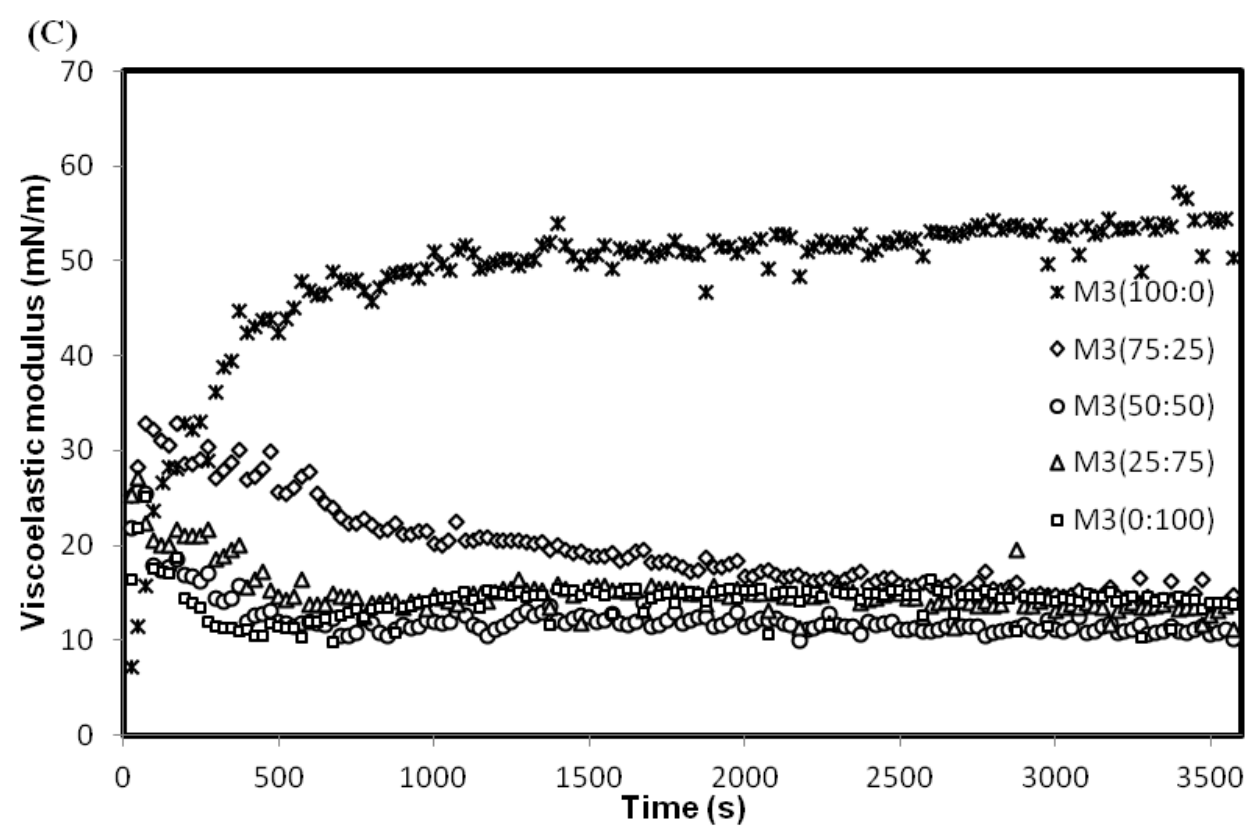

Fig. 5 